\title{
Effects of Fringe Benefits on Employee Loyalty: A Study on University Teachers in Khulna City of Bangladesh
}

\author{
Prosenjit Tarafdar ${ }^{1}$, Kajol Karmoker ${ }^{1} \&$ Sraboni Akter $^{2}$ \\ ${ }^{1}$ Assistant Professor, Human Resource Management Discipline, Khulna University, Bangladesh \\ ${ }^{2}$ Independent Researcher, Human Resource Management Discipline, Khulna University, Bangladesh \\ Correspondence: Kajol Karmoker, Human Resource Management Discipline, Khulna University, Khulna 9208, \\ Bangladesh
}

Received: July 4, 2021

Accepted: August 18, 2021

Online Published: September 10, 2021

doi:10.5430/bmr.v10n3p1

URL: https://doi.org/10.5430/bmr.v10n3p1

\begin{abstract}
The aim of this study was to examine the effects of fringe benefits on employee loyalty in the context of university teachers. The study sample consisted of 100 university teachers who were randomly selected from both private and public universities situated in Khulna city of Bangladesh. Data were collected through a self-administered questionnaire survey. To test the study hypotheses, data were analyzed employing correlation and multiple regression analysis tools. Results of correlation analysis reveal that fringe benefits (insurance \& retirement benefits, payments for time not worked, education \& development opportunities, flexible working hours, and employee welfare benefits) are positively related to employee loyalty. Regression statistics shows that $25.6 \%$ variance of employee loyalty can be explained by the fringe benefits. The study findings also indicate that flexible working hours $(\beta=0.296$, Sig. $=0.001)$ has the most significant contribution in explaining employee loyalty among the university faculty members employed in Khulna city of Bangladesh.
\end{abstract}

Keywords: fringe benefits, flexible working hours, employee loyalty, university teachers, Bangladesh

\section{Introduction}

Compensation is essential for retaining the workforce and keeping them motivated. Compensation may take the form of financial and non-financial benefits (Michael et al., 2016). Employees are financially compensated in two waysdirectly and indirectly. The indirect form of financial benefits is called fringe benefits (Hayes \& Ninemeier, 2009). Fringe benefits are various kinds of indirect reimbursement given to a group of employees in addition to their wages (Mathis \& Jackson, 2003). The most common form of fringe benefits is free accommodation, bonuses, incentives, commission, sick leaves, annual leaves, lunch facilities, overtime pay, mobile bills, transportation bills, cafeteria services, training facilities, flexible working hours, and so on (Ahmad \& Scott, 2015). Simply, the aim of designing employee benefit packages is to offer an attractive compensation package with a view to retaining high-quality employees. Benefits offered by an organization mainly aims at converting employees to pleased employees who become loyal and productive (Ahmad \& Scott, 2015). Employee loyalty is a state of mind of an employee that provides feelings of belongingness to the organization he/she works for. A loyal employee is one who can sacrifice personal interest for the interest of the organization he/she works for, feels devoted to organization's success and commits not to leave the organization (Guillen \& Cezanne, 2014). Employee loyalty is a consequence of employee satisfaction (Metzger \& Renzo, 2006) while it's well recognized that employee satisfaction is a direct consequence of employee benefits that include fringe benefits. Employee loyalty plays positive role in improving organizations' service quality (Yee et al., 2010) and superior service quality increases organizational profitability through creating loyal customers. Since fringe benefits work as a stimulator of job satisfaction which is the primary reason for employees in becoming loyal towards the organization, there is a positive relationship between fringe benefits and employee loyalty (Arts, 2010; Ahmad \& Scott, 2015). Employees who are satisfied with their jobs are most likely to be more loyal to an organization than dissatisfied employees. It is proven that when employee satisfaction increases, organizational loyalty of employees also gets higher while a decrease in employee job satisfaction leads to a decrease in employee loyalty (Kim et al., 2005). Consequently, it is well recognized that committed and satisfied employees hardly leave their organization and fringe benefits work as a stimulator of employee satisfaction and commitment. 
Effects of fringe benefits on employee loyalty have been studied in several sectors, such as banking sector (Phuong \& Tien, 2013), hotel and restaurant sector (Phuong et al., 2020). But, few studies exist in the educational sector connecting the issue of fringe benefits with employee loyalty. The educational system comprises of three key elements- teachers, students, and curriculum and the most important element is teachers because the efficiency and effectiveness of an education system depend on them. The satisfaction level of a teacher is a central and crucial concern for universities in Bangladesh. If these Universities want to contribute to society, then they must create a good combination of benefits to satisfy their faculty members. A pleasant and positive attitude develops among the teachers once they are satisfied with their jobs (Millan et al., 2011). Previously, many researches have been conducted on the importance of fringe benefits and their impact on employee satisfaction, retention, and productivity. But in this study, we have investigated the effects of various types of fringe benefits on employee loyalty. Such study among university teachers is unique, especially in Bangladesh. This study is obvious to be helpful for the employers (universities) in adapting and designing fringe benefits for the university teachers of Bangladesh.

\section{Conceptual Framework}

\subsection{Fringe Benefits}

Fringe benefits are some additions, not in from of money, to employee compensation that are beyond annual or monthly salary (Podgursky, 2003). Such benefits are stated as the remuneration provided by the employer to the employees in exchange of their contribution to the organization (Sharma et al., 2018). Fringe benefits comprise of both material and non-material incentives that any organization offers to its employees to increase their commitment to the organization (Bradley \& Stephens, 2007). Moonman (1973) finds that individual fringe benefits include legally required payments, pension, insurance along with other agreed-upon payments, paid rest periods, lunch periods, travel time, and payments for time not worked. Ahmad and Scott (2015) define fringe benefits as the benefits of paid annual leave, free accommodation, and insurance coverage. Moreover, Hayes and Gaskell (2007) conclude that fringe benefits mainly include three main parts: obvious benefits, inevitable labor benefits, and hidden benefits. Among the three, obvious benefits which include social security, retirement, and insurance are the most popular benefits offered by most organizations. Galanaki (2013) also claims that fringe benefits are the ways of making the employees and their family members happy to the organization. The concept of fringe benefits in employment policies has gained popularity in recent years since it creates a positive atmosphere where employees can work with a stress-free mind. Fringe benefits are more effective for employee satisfaction and commitment because if employees perceive that the amount or benefits that they are offered are beyond the law, they become loyal to the organization (Ahmad \& Scott, 2015).

\subsection{Employee Loyalty}

Loyalty represents a person's devotion to a particular object (Pandey \& Khare, 2012). Employee loyalty is defined as an employee's willingness to stay in the same organization and belief that working for the current organization is the best option rather than searching for the alternative employment choice (Pandey \& Khare, 2012). Employee loyalty is also treated as an organizational citizenship behavior which means a devotion that the employees put in their work (Bettencourt et al., 2001). It's an expression of organizational commitment to the success of the organization, an individual's identification and involvement in an organization (Mowday et al., 1982). It has been found that employee loyalty can be influenced by a number of things, such as age, length of service in the organization, payroll, work design, leadership style, job characteristics, employers treatment, fair promotion system, training and development opportunities, incentives to the best performing employees, organizations social image, social acceptance, etc. Change in any of these factors may result in change in employee's loyalty to the organization. Kim et al. (2005) argue that employees who are satisfied with their jobs are most likely to be more loyal to the organization than dissatisfied employees and it is also proven that when the employee job satisfaction increases, the degree of organizational loyalty of employees also gets higher. On the other hand, when the employee job satisfaction decreases, it leads to the decrease of employee loyalty (Kim et al., 2005). Walker (2006) also finds that employees become loyal to those organizations which offer the opportunities to learn, grow, and provide a clear career path. So, the fringe benefits in the form of financial and non-financial benefits are the significant and positive determinants of employee job satisfaction which ultimately affect their continuation in a job position (Kasper et al., 2012).

\section{Hypotheses Development}

As stated earlier, fringe benefits can be of many types covering both financial and non-financial benefits. Financial benefits include commissions, bonuses, profit sharing, share options whereas non-financial benefits include holidays, sick pay, medical insurance, and so on (Bernadin, 2007). All these financial and non-financial benefits can be grouped into five types of fringe benefits: insurance and retirement benefits, payments for time not worked, education and 
development opportunities, flexible working hours, and employee welfare benefits. The following section describes the relationship between each type of fringe benefits and employee loyalty.

\subsection{Insurance \& Retirement Benefits and Employee Loyalty}

Insurance and retirement benefits are the most important type of fringe benefits which include medical/health insurance, provident fund scheme, pension scheme, gratuity, and earned leave benefits (Fronstin, 2013). Since, employee health and overall productivity of the firm are inter-related, many firms design the employee health security benefit programs for their workforce (Kamau, 2013). Employee life Insurance program and group insurance coverage at the organizational level are such kind of health security programs which help in protecting employees in contrast to a loss of income due to illness, accident, or accidental death (Okumbe, 2001). Life insurance coverage reduces worry about one's family security which in turn leads to greater concentration on their works. On the other hand, retirement benefit program permits an employer to make a retirement plan or pension plan for their employees when they quit their jobs after a specific period (Achieng, 2011). Pension plans or retirement plans are funded by the employer and invested to grow the funds that would later be used for paying retirees after a certain age. It gives the employees a feeling of power by having some control over planning for retirement. Kasper et al. (2012) also argue that retirement benefits are of great value for employees' private life, especially with regard to social security. These benefits make the employees feel secured at their workplace and loyal to that organization. Consequently, retirement benefits and insurance coverage offered by the companies make a certain future for the employees which ultimately encourage them to stay at the same organization (Ahmad \& Scott, 2015). Thus the authors develop the following hypothesis in relation to insurance and retirement benefits.

\section{H1: Insurance \& retirement benefits provided by the organization relates positively to employee loyalty.}

\subsection{Payment for Time not Worked and Employee Loyalty}

Payment for time not worked, also called supplemental pay benefit is a type of benefit for employees for the period they are off to work. It refers to the compensation during maternity leave, paternity leave, adoption leave, sick leave, leave for civic duty, lunch rest, personal leave etc. (Artz, 2010). According to the leave policy, most common form of leave is sick leave (Naithani, 2010). King et al. (2012) suggest that the employees who are given sick leave facility by the employers tend to recover quicker from illness than others. Moreover, Casper et al. (2011) state that the employers who offer paid sick leave are more likely to have performance better than those who are unwilling to offer paid sick leaves. Besides, sick leave ensures that employees will earn their wages or salaries in times of illness. Payment for time not worked is now a days a confronting issue for employers and gradually becoming an issue to be given more importance because of its impact on employee satisfaction. Nisar and Siddiqui (2019) find that payment for time not worked appears the most important type of fringe benefit when it comes to the level of satisfaction of employees since it has a significant positive impact on employee satisfaction. The more employees have paid time off, the more they are relaxed and less distracted from their responsibilities over their professional lives. Galanaki (2013) reports that the most important fringe benefits for employees are those which help to make a balance between work and family life. In his study, maternity leave, death leave, and compassionate leave are found to be positively correlated with organizational commitment and job loyalty. Therefore, we expect the following relationship.

\section{H2: Payment for time not worked provided by the organization relates positively to employee loyalty.}

\subsection{Education \& Development Opportunities and Employee Loyalty}

Education \& development programs include arranging in-house training programs, e-training programs, seminars, and workshops for personnel development (Artz, 2010). These programs typically cover partial or full costs of training and formal educational programs either inside or outside the country. Costs of such programs typically include training costs, costs of books, laboratory materials and tuition fees. Education and development opportunities allow the employees to advance additional knowledge, skills, and expertise which eventually bring benefits to the organization, such as increased level of productivity and efficiency. Some companies offer these opportunities to increase employee knowledge which ultimately motivate and make the employees committed to the organization (Rhoades \& Eisenberger, 2002). In addition to this, in some organizations, educational fees for the employees' children are paid up to a certain academic level and age. These programs have been found to increase employee retention rate and decrease employee turnover intention rate. Professionals working in universities and research institutions can be easily motivated through training or schooling (Mathis, 2003). It can be said that enterprise featured orientation programs can make the employees adopt the corporate culture, increase commitment to the organization and enable them to get used to their colleagues and the organization. While conducting research in various sectors Galanaki (2013) also found that many employers offer education \& development opportunities for their employees to prevent employee burnout and to retain 
talented employees. Therefore, in relation to education \& development and employee loyalty, we can hypothesize the following relationship.

H3: Education and development opportunities provided by the organization relate positively to employee loyalty.

\subsection{Flexible Working Hours and Employee Loyalty}

Flexible working hours refer to some control over one's working hours (Gregg, 1998). This is known as the variation in job's time and place which permits the worker to perform job-related duties without complying with the standard working hours (Jenks et al., 2010). Flexible working hour arrangement includes working opportunity from home, flextime, location, flexible job scheduling, and job sharing (Artz, 2010). Such arrangements have been found to have a positive impact on job satisfaction. Jenks et al. (1993) also report that flexible work plan has a positive influence on employee productivity, attendance, and morale. Having increased access to a flexible working hour is a source of motivation for all the working employees since flexible work plan allows employees to adjust their working conditions (Jansen et al., 2010). Thus, many organizations consider flexible working hours as one of the vital benefits provided to the employees. Yavuz (2004) claims that flexible working hours is the most frequently used non-monetary incentive provided to the employees. As flexible working hours help organizational employees arrange their work in an easy schedule without compromising productivity, it has an impact on the employee satisfaction which in turn stimulate the employees to remain and work for the same organization (Nisar \& Siddiqui, 2019). Thus, the organizations adopt flexible working policy measures so that the employees become inspired to work for a long time in the same organizations instead of looking for the alternative job offers. Therefore, we can draw the following hypothesis in terms of the relationship between flexible working hours and employee loyalty.

H4: Flexible working hours provided by the organization relates positively to employee loyalty.

\subsection{Employee Welfare Benefits and Employee Loyalty}

Employee welfare benefits include canteen, sports, clubs, cafeterias, sanitation, child care centers, purchase discounts, transportation, housing, house building loans, legal aid, parties, picnics etc. Okumbe (2001) argues that sports programs like football, cricket, handball, swimming, indoor games at clubs, tennis, golf, volleyball etc. are the sources of employee entertainments which create an affection to the organization. Canteen or cafeteria facilities not only help workers purchase food at a minimum cost but also help in improving the nutritional needs of employees. Moreover, purchase discounts offered by the organizations permit employees to purchase products or services at a reduced price which eventually increases employee satisfaction. Employee satisfaction can further be enhanced if they are provided with the child care centers, transport benefits in the form of monthly transport allowance or car allowance (Gunkel et al., 2009; Lin et al., 2010). Even with the housing facilities offered by organizations, employees can meet one of their basic needs (Andrews, 2009). Consequently, welfare benefits offered for improving employee living standard let them feel themselves as a part of their enterprise. It's not an issue of secrecy that employees being motivated by the internal working conditions tend to perform better and accomplish more (Shelton et al., 2011). Furthermore, Pichler \& Wallace (2009) report that employee commitment and loyalty to the organization increase with the benefits that improve the employee living standards.

H5: Employee welfare benefits provided by the organization relate positively to Employee Loyalty.

A conceptual research model has been developed to investigate the relationship between fringe benefits and employee loyalty. 
Fringe Benefits

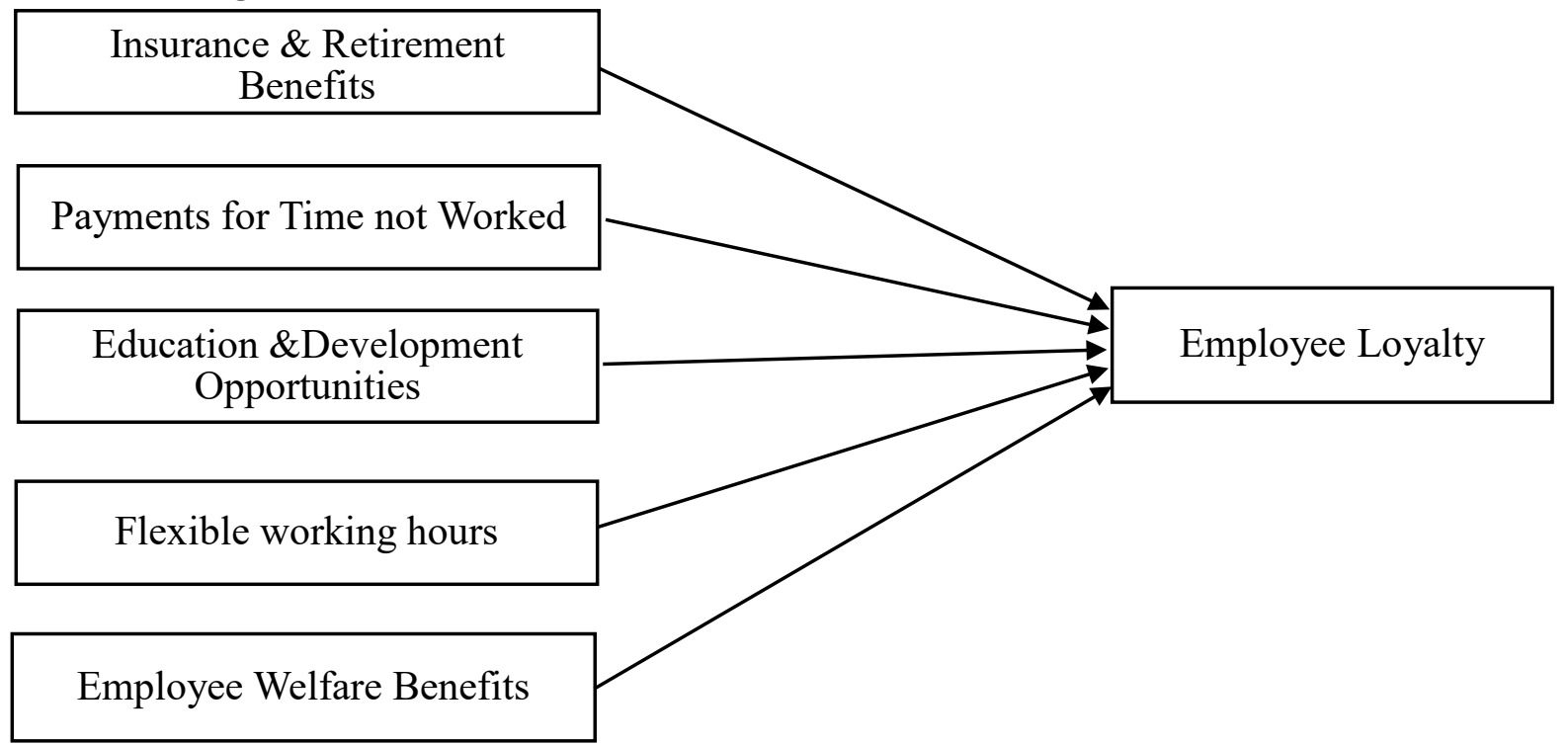

Figure 1. Conceptual Research Model

\section{Methodology}

\subsection{Participants and Procedure}

Since the study was conducted with the purpose of investigating the effects of fringe benefits on employee loyalty among the university teachers, a quantitative research design was applied. Data were collected from 100 university teachers working either in private or public universities situated in Khulna city of Bangladesh. It was found that $66 \%$ of respondents were aged from 25 to $34,23 \%$ were aged from 35 to $44,7 \%$ were aged from 45 to $54,1 \%$ were aged from 55 to 64 and $3 \%$ were aged above 64 . In terms of gender, $67 \%$ of employees were male and $33 \%$ were female. Out of 100 teachers, $44 \%$ were lecturers, $41 \%$ were assistant professors, $9 \%$ were associate professors and $6 \%$ were professors. Approximately 59\% of respondents had job experience of $0-4$ years, $29 \%$ had $5-10$ years, $6 \%$ had $11-15$ years, 5\% had 16-20 years and the rest had job experience of above 20 years. Data used in this study were collected through a self-administered questionnaire which was distributed either face to face or through email. First part of the questionnaire was designed to solicit demographic information of the respondents. Second part of the questionnaire was designed with the statements over insurance and retirement benefits, payments for time not worked, education and development opportunities, flexible working hours, employee welfare benefits and employee loyalty. For responding each of the statements in the second part, 5-point Likert scale (Strongly Disagree=1 to Strongly Agree $=5$ ) was used.

\subsection{Measurements}

We measured the fringe benefits using the scale developed by Galanaki's (2013) and Artz (2010) with slight modification according to the current research context. Out of 27 items for fringe benefits, insurance and retirement benefits were assessed by four items covering provident fund, gratuity, life insurance, health insurance plan, and accidental insurance plan. A typical scale item was" I am happy with my health insurance plan". Payments for time not worked were measured via a four-item index that covers annual leave, sick leave, paternity/maternity leave, and paid compassionate leave. A typical scale item was "For the sick leave, I get full compensation". Education and development opportunities were measured using a five-item instrument that focused on the employees' in-house and external training, conference and training, e-training, and personal and career growth. A typical scale item was "My organization gives, me an opportunity for educational training both inside and outside the country". Flexible working hours were measured via a four-item index. A typical scale item was "I can use flexible schedule for my duties". Employee welfare benefits were measured using a ten-item instrument that focused on cafeteria service, transportation facilities, gift vouchers, rent allowances, marriage allowances, child care centers, teachers' clubs, medical facilities, computer facilities, and purchasing house, car, furniture loan. A typical scale item was "I can get advance money for purchasing house, car, and furniture and so on". Employee loyalty was measured using a five-item scale adopted from 
Pandey and Khare (2012). The five-item scale focused on university teacher's attitude towards fringe benefits and their eagerness for the job. A typical scale item was "I recommend my university to the potential students".

\section{Data Analysis}

\subsection{Reliability of Measure}

To check the reliability of the study variables namely insurance and retirement benefits, payments for time not worked, education and development opportunities, flexible working hours, employee welfare benefits, and employee loyalty, Cronbach's alpha score was computed. Table 1 of reliability analysis states that all the variables used in the study have a Cronbach's alpha score of above 0.70 except the variable Payments for Time not Worked. This finding suggests that measurement of the variables is valid and reliable for further analysis.

Table 1 . Reliability analysis

\begin{tabular}{lc}
\hline Items & ' $\boldsymbol{\alpha}$ 'score \\
\hline Independent Variables & 0.720 \\
Insurance and Retirement Benefits & 0.682 \\
Payments for Time not Worked & 0.842 \\
Education and Development & 0.801 \\
Flexible Working Hours & 0.789 \\
Employee Welfare Benefits & \\
Dependent Variable & 0.875 \\
Employee Loyalty & \\
\hline
\end{tabular}

\subsection{Hypotheses Testing}

Five hypotheses were developed to understand the association between fringe benefits and employee loyalty. The hypotheses were tested employing correlation and multiple regression analysis. Pearson product-moment correlation coefficient illustrated in Table 2 shows that there is a positive relationship between each of the independent variables and dependent variable. Findings of correlation analysis supports all the hypotheses indicating that fringe benefits are positively related to employee loyalty. However, multiple regression analysis (Table 3 ) was also conducted in order to measure the significant influence of the five predictors on employee loyalty. As illustrated in Table 3, it is observed that $R^{2}$ is 0.256 which indicates that $25.6 \%$ variance in employee loyalty can be explained by the predictors. The overall model was reasonably fit with the $\mathrm{F}$ statistics of 6.483 and $\mathrm{P}<0.01$. Individual variables of the model reveal that only flexible working hours $(\beta=0.296$, Sig. $=0.001)$ has significant contribution in explaining employee loyalty since Sig. value is less than 0.05 . Insurance and retirement benefits, $(\beta=0.154$, Sig. $=0.133)$, payments for time not worked, ( $\beta=0.030$, Sig. $=0.788)$, education and development $(\beta=0.147$, Sig. $=0.134)$, employee welfare benefits $(\beta=0.033$, Sig. $=0.816$ ), were not found significant to explain employee loyalty since the Sig. value was more than 0.05 .

Table 2. Pearson product-moment correlations between study variables

\begin{tabular}{|c|c|c|c|c|c|c|}
\hline Variables & 1 & 2 & 3 & 4 & 5 & 6 \\
\hline 1. Insurance \& Retirement Benefits & 1 & & & & & \\
\hline 2. Payments for Time not Worked & $0.337 * *$ & 1 & & & & \\
\hline 3. Education and Development & $0.355^{* *}$ & $0.447 * *$ & 1 & & & \\
\hline 4. Flexible Working Hours & 0.167 & $0.384 * *$ & $0.209 *$ & 1 & & \\
\hline 5. Employee Welfare Benefits & $0.514 * *$ & $0.539 * *$ & $0.544 * *$ & $0.316^{* *}$ & 1 & \\
\hline 6. Employee Loyalty & $0.314 * *$ & $0.337 * *$ & $0.322 * *$ & $0.405 * *$ & $0.324 * *$ & 1 \\
\hline
\end{tabular}

**. Correlation is significant at the 0.01 level (2-tailed).

*. Correlation is significant at the 0.05 level (2-tailed). 
Table 3. Regression Statistics

\begin{tabular}{lllll}
\hline Independent Variables & B & SE & B & P \\
\hline Insurance and Retirement Benefits & 0.154 & 0.102 & 0.170 & 0.133 \\
Payments for Time not Worked & 0.030 & 0.109 & 0.033 & 0.788 \\
Education and Development & 0.147 & 0.097 & 0.164 & 0.134 \\
Flexible Working Hours & 0.296 & 0.090 & 0.321 & 0.001 \\
Employee Welfare Benefits & 0.033 & 0.142 & 0.028 & 0.816 \\
$R$ & 0.506 & & & \\
$R^{2}$ & 0.256 & & & \\
F-Statistic & 6.483 & & & \\
Adj. $R^{2}$ & & & \\
$N$ & 0.217 & & \\
\hline
\end{tabular}

Notes. $* \mathrm{P}<0.05 ; * * \mathrm{P}<0.01$.

Dependent Variable: Employee loyalty.

\section{Result Discussion}

In terms of the relationship between insurance and retirement benefits and employee loyalty, it is found that there is a positive relationship between the variables $\left(\mathrm{r}=0.314^{* *}\right)$, but the relationship is not significant in explaining employee loyalty. This might be because the incorporation of insurance and retirement benefits are insufficient in the compensation package of the university teachers working in either private or public universities in Khulna city of Bangladesh. Consequently, the result contradicts the study outcomes of Hayes and Gaskell (2007) in which they explained that most organizations include insurance and retirement benefits which discourage the employees to leave the organization, ultimately increasing employee loyalty.

A positive association $\left(r=0.337^{* *}\right)$ has also been found in the relationship between payments for time not worked and employee loyalty, but the relationship is not significant indicating that payments for time not worked do not have any significant influence on employee loyalty. But, Casper et al. (2012) proved that payments for maternity leave, paternity leave, and adoption leave, play as a motivating factor to improve employee performance and to reduce employee turnover intention. So, the current study findings are opposing the findings of Casper et al. (2012).

According to the study findings, education and development opportunity is found to be positively related with employee loyalty $\left(r=0.337^{* *}\right)$, but the relationship is not found significant. This is because of the reasons that education and development opportunities are rarely offered to the university faculty members working in Khulna city of Bangladesh. But, it is recommended that providing employees with educational and development opportunities can increase loyalty towards the organization. The results clash with the findings of Mathis (2003) in which it was found that educational allowance paid by few organizations has significant influence on employee loyalty.

In terms of the relationship between flexible working hours and employee loyalty, it is found that there is a positive relationship $\left(\mathrm{r}=0.337^{* *}\right)$ and the relationship is significant to influence employee loyalty. The results advocate that employee loyalty can be increased if flexible working hours instead of tight working schedules are provided to the employees. This findings are in line with the evidence of Galanaki (2013) who argued that flexible working arrangements such as work time flexibility or the possibility to work from home, flextime, and job sharing can add value to the employer which in turn positively affect employee loyalty.

In relation to employee welfare benefits and employee loyalty, it is also found that there is a positive relationship between the variables $\left(r=0.337^{* *}\right)$, but employee welfare benefits are not significant enough to influence employee loyalty. This result challenge the findings of Galanaki (2013) who concluded that employee service benefits, such as child care center, workplace restaurant, transport allowance, leave for special social occasions, low interest rate loan or advance payments of salary, providing mobile phones, computers, and car facilities or car loan can significantly enhance employee loyalty. 


\section{Conclusion and Recommendations}

The main purpose of the study was to investigate the effects of fringe benefits on employee loyalty. The study established that insurance \& retirement benefits, payment for time not worked, education \& development opportunities, flexible working hours, and employee welfare benefits contribute to employee loyalty positively. Based on the study findings, it is suggested that the university administration should continue providing all kinds of fringe benefits to the teachers and introduce some new forms of such benefits if required since the benefits positively affect employee loyalty. The universities are also recommended to make their teachers aware of the fringe benefit programs that they offer because most of them do not have accurate idea about their benefit programs they are entitled to enjoy. Moreover, since it has been proved that flexible working hour has the most significant impact on employee loyalty, the universities should be more careful about maintaining such facility. The organization should also try to be more open for child care center in the organization premises. Priorities should be given to education and development opportunities which are limited or sometimes no arrangements for adequate in-house and external training for personal and career growth. Universities should also work on medical facilities and health insurance plan. So, the findings of the study have several implications for university authorities and policy makers when designing fringe benefits for the university teachers. Furthermore, the study findings can help different organizational practitioners to develop strategies and policies to enhance employee loyalty.

\section{Limitations and Directions for Future Research}

Like any other study, the current study has also few limitations. Firstly, the current study has shown only the direct effects of fringe benefits on employee loyalty without considering any moderating or mediation effects. In future, it is suggested to conduct research taking into account the moderating effects of employee gender, age, self-efficacy, and confidence level. Mediation effects of employee satisfaction or employee commitment must be explored for a better understanding of the relationship between fringe benefits and employee loyalty. Secondly, the study was conducted only on the university teachers selected from only Khulna city, Bangladesh. Consequently, the study findings may not be generalized in other regions. Future researchers need to conduct study taking sample from other regions of the country, even from different universities of the world in order to achieve better generalization of the findings.

\section{Acknowledgments}

Though this is a self-funded study, we convey our special thanks to those individuals who were managed for conducting data collection survey. Above all, we are grateful to the sample teachers who had participated in the survey and spared their valuable time to fill up the questionnaires. We believe that they responded authentically. Thank you all.

\section{References}

Achieng, N. P. (2011). Perceived effects of employee benefits on employee retention at Kenya forest service. $A$ Management Research Project Submitted in Partial Fulfillment for The Degree of Master of Business Administration at University of Nairobi School of Business.

Ahmad, R., \& Scott, N. (2015). Fringe benefits and organisational commitment: The case of Langkawi hotels. Tourism review, 70(1), 13-23. https://doi.org/10.1108/TR-11-2013-0065

Andrews, S. (2009). Human resource management: A textbook for the hospitality industry. Tata McGraw-Hill.

Artz, B. (2010). Fringe benefits and job satisfaction. International journal of manpower, 31(6), 626-644., https://doi.org/10.1108/01437721011073346

Bernardin, H. J. (2007). Human Resource Management. An Experiential Approach. Tata McGraw Hill.

Bettencourt, L. A., Gwinner, K. P., \& Meuter, M. L. (2001). A comparison of attitude, personality and knowledge predictors of service-oriented organizational citizenship behavior. Journal of Applied Psychology, 86(1), 29-41. https://doi.org/10.1037/0021-9010.86.1.29

Bradley, D. H., \& Stephens, J. D. (2007). Employment performance in OECD countries: a test of neoliberal and institutionalist hypotheses. Comparative Political Studies, 40(12), 1486-1510. https://doi.org/10.1177/0010414006292609

Casper, W. J., Harris, C., Taylor-Bianco, A., \& Wayne, J. H. (2011). Work-family conflict, perceived supervisor support and organizational commitment among Brazilian professionals. Journal of Vocational Behavior, 79(3), 640-652. https://doi.org/10.1016/j.jvb.2011.04.011 
Fronstin, P. (2013). Findings from the 2013 EBRI/Greenwald \& associates consumer engagement in health care survey. EBRI Issue Brief, (393).

Galanaki, E. (2013). Gender and the Importance of Fringe Benefits: Exploring their Link with Organizational Commitment and Job Satisfaction. European Academy of Management Conference, Istanbul, Turkey, 26-29. https://doi.org/10.2139/ssrn.2325426

Gregg, L. (1998). Humanity in the workplace: When work/family becomes an HR issue. Credit Union Executive, 38, 32-38. https://onlinelibrary.wiley.com/doi/abs/10.1111/1468-0432.00091

Guillon, O., \& Cezanne, C. (2014). Employee loyalty and organizational performance: a critical survey. Journal of Organizational Change Management, 27(5), 839-850. http://dx.doi.org/10.1108/JOCM-02-2014-0025

Gunkel, M., Lusk, E. J., \& Wolff, B. (2009). Country-compatible incentive design. Schmalenbach Business Review, 61(3), 290-309. 61(3). https://doi.org/10.1007/BF03396788

Hayes, D. K., \& Ninemeier, J. D. (2009). Human resources management in the hospitality industry. John Wiley \& Sons.

Hayes, S., \& Gaskell, S. (2007). Fringe benefits: Obvious and hidden. The Bottom Line, 5(1), 33-35. https://doi.org/10.1108/eb025319

Jenks, J. M., \& Zevnik, B. (1993). Employee Benefits: Plain and Simple: The Complete Step-by-step Guide to Your Benefits Plan. Macmillan Publishing Company.

Jensen, G. A., \& Morrisey, M. A. (2001). Endogenous fringe benefits, compensating wage differentials and older workers. International Journal of Health Care Finance and Economics, 1(3), 203-226. https://doi.org/10.1023/A:1013711501104

Kamau, H. N. (2013). Fringe benefits effects on employee productivity in the public sector (a case of state department of water, Nairobi County, Kenya). Being a Research Project Submitted to the School of Business in Partial Fulfilment of the Requirements for the Award of Degree of Masters in Business Administration (Human Resources Management), Kenyatta University.

Kasper, H., Muehlbacher, J., Kodydek, G., \& Zhang, L. (2012). Fringe benefits and loyalty on the Chinese labour market-a trend towards higher individual-and performance-orientation: A case study focusing on technology companies in the Shanghai region. Journal of Technology Management in China, 7(2), 164-176. http://dx.doi.org/10.1108/17468771211242854

Khuong, M. N., \& Tien, B. D. (2013). Factors influencing employee loyalty directly and indirectly through job satisfaction-A study of banking sector in Ho Chi Minh City. International Journal of current research and academic review, 1(4), 81-95.

Khuong, M., Mai, T., \& Phuong, N. (2020). The impacts of human resource management practices on employees' motivation and loyalty. Management Science Letters, 10(11), 2673-2682. https://doi.org/10.5267/j.msl.2020.3.025

Kim, W. G., Leong, J. K., \& Lee, Y. K. (2005). Effect of service orientation on job satisfaction, organizational commitment, and intention of leaving in a casual dining chain restaurant. International Journal of Hospitality Management, 24(2), 171-193. https://doi.org/10.1016/j.ijhm.2004.05.004

King, R. B., Karuntzos, G., Casper, L. M., Moen, P., Davis, K. D., Berkman, L. \& Kossek, E. E. (2012). Work-family balance issues and work-leave policies. In Handbook of occupational health and wellness, 323-339. https://doi.org/10.1007/978-1-4614-4839-6_15

Lin, Z., Trenberth, L., \& Kelly, J. (2010). The development and implications of China's employee benefit systems. Asia Pacific Journal of Human Resources, 48(3), 287-301. https://doi.org/10.1177/1038411110378958

Mathis, R. L., \& John, H. J. (2003). Human Resource Management (11th ed), OH: Thomson-South-Western, Mason.

Matzler, K., \& Renzl, B. (2006). The relationship between interpersonal trust, employee satisfaction, and employee loyalty. Total quality management and business excellence, 17(10), 1261-1271. https://doi.org/10.1080/14783360600753653

Michael, B., Prince, A. F., \& Chacko, A. (2016). Impact of Compensation Package on Employee Retention. Clear International Journal of Research in Commerce \& Management, 7(10), 36-40. 
Millán, J. M., Hessels, J., Aguado, R., \& Thurik, R. (2011). Determinants of job satisfaction across the eu-15: a comparison of self-employed and paid employees (interactive paper). Frontiers of Entrepreneurship Research, 29(4), 18. https://doi.org/10.2139/ssrn.1766446

Moonman, J. (1973). The Effectiveness of Fringe Benefits in Industry: Including a Survey of Current Practice Undertaken by an Independent Study Group. Epping: Gower Press. https://doi.org/10.1108/eb055234

Mowday, R. T., Steers, R. M., \& Porter, L. W. (1979). The measurement of organizational commitment. Journal of Vocational Behavior, 14(2), 224-247. https://doi.org/10.1016/0001-8791(79)90072-1

Naithani, P. (2010). Overview of work-life balance discourse and its relevance in current economic scenario. Asian Social Science, 6(6), 148-155. https://doi.org/10.1016/0001-8791(79)90072-1

Nisar, S., \& Siddiqui, D. A. (2019). A Survey on the Role of Fringe Benefits in Employee Satisfaction-An Analysis of Organizations of Pakistan. Business Management and Strategy, 9(1), 232-252. https://doi.org/10.5296/ijhrs.v9i1.14162

Okumbe, J. A. O. (2001). Human resources management: An educational perspective. Educational Development and Research Bureau.

Pandey, C., \& Khare, R. (2012). Impact of job satisfaction and organizational commitment on employee loyalty. International Journal of Social Science \& Interdisciplinary Research, 1(8), 26-41.

Pichler, F., \& Wallace, C. (2009). What are the reasons for differences in job satisfaction across Europe? Individual, compositional, and institutional explanations. European Sociological Review, 25(5), 535-549. https://doi.org/10.1093/esr/jen070

Podgursky, M. J. (2003). Fringe benefits: There is more to compensation than a teacher's salary. Economics publications (MU), 3(3), 71-76.

Rhoades, L., \& Eisenberger, R. (2002). Perceived organizational support: a review of the literature. Journal of applied psychology, 87(4), 698. https://doi.org/10.1037/0021-9010.87.4.698

Shelton, C., Gartland, M., \& Stack, M. (2011). The impact of organizational culture and person-organization fit on job satisfaction and organizational commitment in China and the USA. International Journal of Management Development, 1(1), 15-39. https://doi.org/10.1504/IJMD.2011.039952

Walker, R. M., \& Boyne, G. A. (2006). Public management reform and organizational performance: An empirical assessment of the UK Labor government's public service improvement strategy. Journal of Policy Analysis and Management, 25(2), 371-393. https://doi.org/10.1002/pam.20177

Yavuz, N. (2004). The Use of NonMonetary Incentives as a Motivational Tool: A Survey Study in a Public Organization in Turkey (Unpublished Post-Graduate Dissertation, Ankara: Middle East Technical University Institute of Social Sciences).

Yee, R. W., Yeung, A. C., \& Cheng, T. E. (2010). An empirical study of employee loyalty, service quality and firm performance in the service industry. International Journal of Production Economics, 124(1), 109-120. https://doi.org/10.1016/j.jpe.2009.10.015

\section{Copyrights}

Copyright for this article is retained by the author(s), with first publication rights granted to the journal.

This is an open-access article distributed under the terms and conditions of the Creative Commons Attribution license (http://creativecommons.org/licenses/by/4.0/). 